\title{
Detection and extent of extraneous water and adulteration in milk consumed at Hyderabad, Pakistan
}

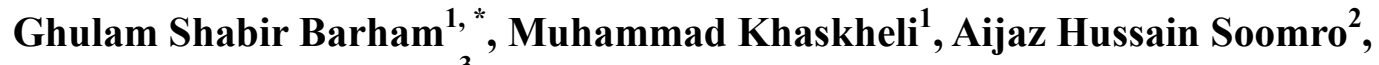 \\ Zaheer Ahmed Nizamani ${ }^{3}$ \\ ${ }^{1}$ Department of Animal Products Technology, Faculty of Animal Husbandry and Veterinary Sciences, Sindh Agriculture University, \\ Tandojam, Pakistan \\ ${ }^{2}$ Institute of Food Sciences and Technology, Faculty of Animal Husbandry and Veterinary Sciences, Sindh Agriculture University, \\ Tandojam, Pakistan \\ ${ }^{3}$ Department of Veterinary Pathology, Faculty of Animal Husbandry and Veterinary Sciences, Sindh Agriculture University, Tandojam, \\ Pakistan
}

\author{
Email address: \\ shabir_dr2010@yahoo.com (G. S. Barham), khaskheli_m@yahoo.com (M. Khaskheli), aijaz68@hotmail.com (A. H. Soomro), \\ zaheer5feb@yahoo.com (Z. A. Nizamani)
}

\section{To cite this article:}

Ghulam Shabir Barham, Muhammad Khaskheli, Aijaz Hussain Soomro, Zaheer Ahmed Nizamani. Detection and Extent of Extraneous Water and Adulteration in Milk Consumed at Hyderabad, Pakistan. Journal of Food and Nutrition Sciences.

Vol. 2, No. 2, 2014, pp. 47-52. doi: 10.11648/j.jfns.20140202.15

\begin{abstract}
This study was designed to screen the various adulterants in the market milk sold in the vicinity of Hyderabad district of Sindh province, Pakistan during the year 2013. A total of 100 milk samples were collected, each of twenty ( $\mathrm{n}=20$ ) from milk producers (MP), milk collectors (MC), middlemen (MM), processors (P) and dairy shops (DS), were examined for various adulterants. Among these adulterants water (91\%) was found in majority of milk samples, followed by detergent $(41 \%)$, cane sugar $(31 \%)$, starch $(27 \%)$, rice flour $(24 \%)$, formalin $(20 \%)$, sodium chloride and skimmed milk powder $(19 \%)$, urea and hydrogen peroxide $(15 \%)$, ammonium sulfate $(13 \%)$, vegetable oil and boric acid (12\%), caustic soda $(11 \%)$, glucose $(10 \%)$, arrowroot $(9 \%)$, hypochlorite (5\%), salicylic acid $(4 \%)$ and sorbitol $(3 \%)$ consumed at the vicinity of Hyderabad district of Sindh, Pakistan. Freezing point of $80 \%$ milk samples of MP, $90 \%$ of MC, $95 \%$ of $\mathrm{MM}, 90 \%$ of $\mathrm{P}$ and $100 \%$ of DS appeared towards $0{ }^{\circ} \mathrm{C}$ rather than that of control milk, and assumed to be adulterated with extraneous water. The averaged extent of water in milk sold by MC remarkably higher than that of other milk marketing channels, but statistically non-significant $(\mathrm{P}>0.05)$ with all milk intermediaries; MP, MC, P and DS, except MM in which the extent of water was found to be significantly $(\mathrm{P}<0.05)$ lower than $\mathrm{MC}$. The risk of adulteration at DS, MM, MC and $\mathrm{P}$ was found non-significant $(\mathrm{P}>0.05)$ with each other, but significantly $(\mathrm{P}<0.05)$ higher than MP.
\end{abstract}

Keywords: Adulteration, Extent of Extraneous Water, Freezing Point and Market Milk

\section{Introduction}

Milk is the best and cheapest source of nutrition and an article of daily diet, easily accepted and used by all the age groups in rural as well as in urban areas. Milk, if present in its natural form, has high food value and supplies good quality nutrients like energy providing lactose and fat, body building proteins, the bone forming calcium, health promoting vitamins and minerals in significant amount than any other single food [1]. Historical evidence indicates that the nations which used to obtain highest calories from milk and milk products were more civilized and capable of having sound administration and such societies enjoy almost complete freedom from nutritional disease. In contrast, the poorly or underdeveloped areas of the world have a primitive or nonexistent milk supply and have numerous inhabitants suffering from nutritional deficiency, especially infants and children [2]. No doubt, milk is a perishable commodity and is likely to be spoiled during summer season when weather becomes very hot [3]. Unfortunately, due to unorganized and non-regulated marketing systems, the quality of milk is hardly maintained at consumer level [4]. In order to keep milk temporarily fresh, some unethical activities are usually practiced to 
prevent the financial losses due to the spoilage of milk during its transportation and sale [5]. For instance, the addition of water to increase volume of milk, thickening agents like starch, flour, skimmed milk powder, whey powder or other ingredients to counter the dilution and extend the solids content of the milk [6]; vegetable oil, sugarcane or urea to compensate the fat, carbohydrate or protein content of diluted milk. Some chemicals such as hydrogen peroxide, carbonates, bicarbonates, antibiotics, caustic soda and even the most lethal chemical formalin to increase the storage period of milk, ice to enhance the shelf life of milk; detergents to enhance the cosmetic nature of milk which diminishes foamy appearance and whitening of milk or calcium thioglycolate / potassium thioglycolate / calcium salts of thioglycolic acid and urea for whitening of milk and giving it a genuine look [7-8]. Adulteration of milk is one of the most serious issues that the dairy sector of Pakistan is facing today, which not only causes major economic losses for the processing industry, but also a major health risk for the consumers. However, the adulteration of milk deteriorates quality of milk may cause serious problems for human health. Like; gastrointestinal problems including gastric ulcer, diarrhea, colon ulcer and kidney problems etc. [9-18]. Therefore, this research was conducted to screen various adulterants and extent of extraneous water in the market milk.

\section{Materials and Methods}

\subsection{Collection of Samples}

An experiment was designed to screen the various adulterants in the market milk at the vicinity of Hyderabad district of Sindh, Pakistan. A total of 100 unprocessed milk samples were collected and sampling of milk was performed from each of twenty $(n=20)$ milk producers (MP), milk collectors (MC), middlemen (MM), processors (P) and dairy shops (DS). All the market milk samples were collected in sterilized labeled screw capped glass bottle, kept in icebox and immediately brought to the Dairy analytical laboratory of the Department of Animal Products Technology, Faculty of Animal Husbandry and Veterinary sciences, Sindh Agriculture University Tandojam, and stored at $4-8^{\circ} \mathrm{C}$ till analysis.

\subsection{Screening of Various Adulterants}

All the milk samples were screened for the presence of different adulterants through commercially available milk adulteration testing kit [3\&19].

\subsection{Presence and Extent of Extraneous Water}

Presence and extent of extraneous water in milk samples was detected by depression of freezing point (through Cryoscope) and calculated by using following formula [20].

$$
\% \text { water added }=\frac{\text { Freezing point base }- \text { observed freezing point }}{\text { Freezing point base }} * 100
$$

\subsection{Data Analysis}

The data obtained was subjected to analysis of variance (ANOVA) significant differences of the means were computed using least significant difference (LSD) through computerized statistical package i.e. Student Edition of Statistix (SXW), Version 8.1 (Copyright 2005, Analytical Software, USA).

\section{Result}

\subsection{Detection of Adulterant in Market Milk}

Market milk samples randomly collected from different milk sale points at vicinity of Hyderabad district, viz. milk producers (MP), milk collectors (MC), middlemen (MM), processors (P) and dairy shops (DS) were examined for different adulterants. Results presented in $\square$ fig. $1 \square$ showed that the water was the most common adulterant $(90 \%)$ found to be in the majority of milk samples, followed by detergent $(41 \%)$, cane sugar $(31 \%)$, starch $(27 \%)$, rice flour $(24 \%)$, formalin $(20 \%)$, sodium chloride and skimmed milk powder $(19 \%)$, urea and hydrogen peroxide $(15 \%)$, ammonium sulfate $(13 \%)$, vegetable oil and boric acid $(12 \%)$, caustic soda (11\%), glucose (10\%), arrowroot (9\%), hypochlorite (5\%), salicylic acid (4\%) and sorbitol (3\%), respectively.

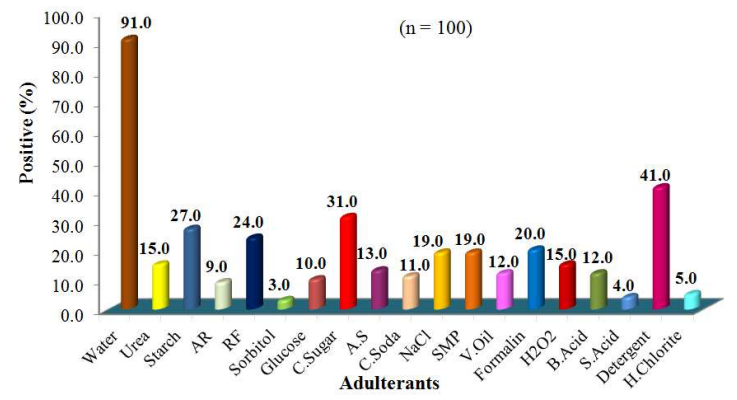

Figure 1. Positive percent of various adulterants detected in market milk samples of Hyderabad, Pakistan

Legends: $\mathrm{AR}=$ Arrowroot, $\mathrm{RF}=$ Rice flour, $\mathrm{AS}=$ Amonium sulfate, C.Sugar $=$ Cane sugar, C.Soda $=$ Caustic soda, $\mathrm{NaCl}=$ Sodium chloride, $\mathrm{SMP}=$ Skimmed milk powder, V.Oil = Vegetable oil, $\mathrm{H} 2 \mathrm{O} 2=$ Hydrogen peroxide, B.Acid = Boric acid, S.Acid = Salicylic acid, H.Chorite $=$ Hypochlorite

\subsection{Freezing point of milk sold at different intermediaries}

Results in Table-1 showed that the average freezing point of control milk $(-0.540 \pm 0.0030 \mathrm{C})$ varied considerably $(\mathrm{P}<0.05)$ from the milk MP $(-0.431 \pm 0.180 \mathrm{C})$, MM, ($0.444 \pm 0.2220 \mathrm{C}), \mathrm{P}(-0.414 \pm 0.0180 \mathrm{C}) \mathrm{DS}(-0.340 \pm 0.0170 \mathrm{C})$ and MC (-0.331 $\pm 0.0510 \mathrm{C})$, respectively. While, The least significant difference (LSD, 0.05) of mean test revealed no significant difference $(\mathrm{P}>0.05)$ in average freezing point of milk sold by MP, MM and DS, while there was a significant difference $(\mathrm{P}<0.05)$ in freezing point of milk sold by MC and MM.

Moreover, the results presented in $\square$ fig. $2 \square$ showed that $80 \%$ milk samples of MP, $90 \%$ of MC, $95 \%$ of MM, $90 \%$ 
of $\mathrm{P}$ and $100 \%$ of milk sold at DS did not show similarity with freezing point of control milk $(-0.522$ to $-0.5610 \mathrm{C})$ and assumed to be positive, adulterated with extraneous water, while $20,10,5,10$ and $0 \%$ samples were in range of freezing point of control milk samples and assumed to be negative, respectively.

Table 1. Freezing point of market milk sold by different intermediaries at Hyderabad, Pakistan

\begin{tabular}{|c|c|c|c|c|c|c|c|c|}
\hline \multirow{2}{*}{$\begin{array}{c}\text { Descriptive } \\
\text { measures }\end{array}$} & \multirow[b]{2}{*}{ Control } & \multicolumn{4}{|c|}{ Freezing point of milk $\left({ }^{\circ} \mathrm{C}\right)$} & \multirow[b]{2}{*}{ DS } & \multicolumn{2}{|c|}{ Significance } \\
\hline & & MP & $\mathrm{MC}$ & MM & $\mathbf{P}$ & & P-value & LSD $(0.05) \pm$ SE \\
\hline Minimum & -0.561 & -0.560 & -0.531 & -0.522 & -0.543 & -0.497 & \multirow{4}{*}{$<0.001$} & \multirow{4}{*}{$0.047 \pm 0.024$} \\
\hline Maximum & -0.522 & -0.231 & -0.193 & -0.334 & -0.279 & -0.256 & & \\
\hline Mean* & $-0.540^{\mathrm{c}}$ & $0.431^{\mathrm{ab}}$ & $-0.331^{\mathrm{a}}$ & $-0.444^{b}$ & $-0.414^{\mathrm{ab}}$ & $-0.340^{\mathrm{ab}}$ & & \\
\hline $\mathrm{SE} \pm$ & 0.0027 & 0.018 & 0.051 & 0.122 & 0.018 & 0.017 & & \\
\hline
\end{tabular}

*Means with different letters in same row varied significantly from one another.

Legends: $\mathrm{MP}=$ Milk producers, $\mathrm{MC}=$ Milk collectors, $\mathrm{MM}=$ Middlemen, $\mathrm{P}=$ Processors and $\mathrm{DS}=$ Dairy shops.

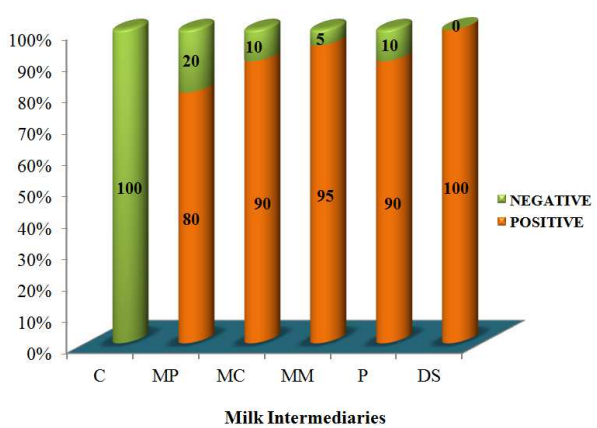

Figure 2. Market milk samples (\%) varied in freezing point from control milk collected from different intermediaries at Hyderabad, Pakistan

*Milk samples with freezing point below the range of control milk (-0.522 to $-0.5610 \mathrm{C}$ )

\subsection{Extent of Extraneous Water in Milk Sold by Different Intermediaries}

Extent of extraneous water of milk sold by different milk marketing channels was detected from the depression of freezing point. Results in $\square$ Fig. $3 \square$ revealed that the average water percent in milk of $\mathrm{MC}$ was recorded as $28.83 \pm 4.60 \%$ followed by milk of DS $(26.31 \pm 3.20 \%), \mathrm{P}$ $(23.30 \pm 3.41 \%) \quad$ MP $\quad(20.21 \pm 0.36 \%) \quad$ and MM $(16.76 \pm 2.10 \%)$. The mean extent of water in milk sold by MC remarkably higher than that of other milk marketing channels, but statistical analysis (LSD, 0.05) showed no significant differences $(\mathrm{P}>0.05)$ among all milk intermediaries; MP, MC, MM, P and DS. However, the extent of extraneous water found to be comparatively higher $(\mathrm{P}<0.05)$ in milk sold by MC than MM.

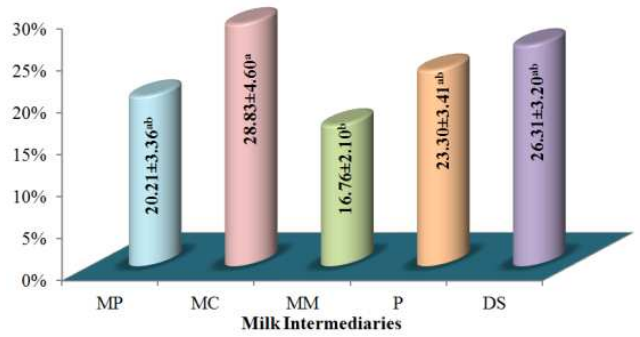

Figure 3. Extent of extraneous water in market milk sold by different intermediaries at Hyderabad, Pakistan

Legends: $\mathrm{MP}=$ Milk producers, $\mathrm{MC}=$ Milk collectors, $\mathrm{MM}=$ Middlemen, $\mathrm{P}=$ Processors, $\mathrm{DS}=$ Dairy shops. $\mathrm{LSD}(0.05)=9.602, \mathrm{SE} \pm=4.836$

\subsection{Extent of Adulteration in Milk Sold by Different Intermediaries}

Results presented in Figure- 4 showed that the extent of adulteration in milk sold at DS $(5.84 \%)$ was found to be higher, followed by MC (5\%), MM (5.11\%), P (2.79\%) and MP (1.26\%), respectively. Statistical analysis (ANOVA) showed that the risk of adulteration at DS, MM, MC and $\mathrm{P}$ was statistically non-significant $(\mathrm{P}>0.05)$ with each other, but significantly higher $(\mathrm{P}<0.05)$ than that of MP.

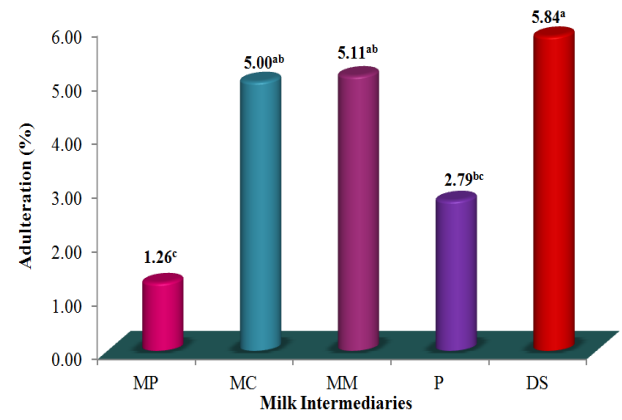

Figure 4. Extent of adulteration in market milk sold by different intermediaries at Hyderabad, Pakistan

Legends: $\mathrm{MP}=$ Milk producers, $\mathrm{MC}=$ Milk collectors, $\mathrm{MM}=$ Middlemen, $\mathrm{P}=$ Processors and DS $=$ Dairy shops. $\operatorname{LSD}(0.05)=2.727, \mathrm{SE} \pm=1.372$

\section{Discussion}

Water (91\%) was the common adulterant found in majority of milk samples collected from different intermediaries at the vicinity of Hyderabad during the present study. Milk adulteration, poor hygiene, lack of preservation technology, cooling facilities and sanitation conditions are the main causes of losses in quality of milk [9]. The milk supply is reduced in summer due to fall $(55 \%)$ in milk production and increase in demand (60\%) compared to winter when milk supply is ample. To cope with demand, water is admixed with whole milk to increase the volume of milk during summer season [21]. Similarly, the freezing point of milk samples collected from different intermediaries was significantly $(\mathrm{P}<0.05)$ varied from control milk samples. Milk containing extraneous water will have a grossly elevated freezing point. In the present study the extent of extraneous water found to be comparatively higher $(\mathrm{P}<0.05)$ in milk sold at $\mathrm{DS}, \mathrm{MC}, \mathrm{P}$ 
and MM than that of milk sold by MP [22-23]. Similar observations have been reported by different researchers the extent of extraneous water was found to be higher in market milk samples and the ratio of adulteration in milk was high in urban areas as compared to the rural areas [22 and 24]. Milk samples collected from milk vendors were highly adulterated with water than samples collected from dairy farms. For the fulfillment of the gap between demand and supply different milk marketing dealers adulterated the milk by adding water which is probably carried out during the handling of milk starting from milking till it reaches the consumer or end user [25-26]. Milk dealers add dirty ice to increase the shelf life of milk which is also one of the reasons of elevated level of extraneous water in milk samples [7]. It has been noticed that addition of water to normal whole milk was assumed to increase the quantity of milk. The Gawalas/dhodis tend to mix muddy water rather than clean tap water in order to increase density and keep milk thicker [27 and 21]. Similarly, other adulterants like detergent $(41 \%)$, cane sugar $(31 \%)$, starch $(27 \%)$, rice flour (24\%), formalin (20\%), sodium chloride and skimmed milk powder $(19 \%)$, urea and hydrogen peroxide (15\%), ammonium sulfate $(13 \%)$, vegetable oil and boric acid $(12 \%)$, caustic soda $(11 \%)$, glucose $(10 \%)$, arrowroot $(9 \%)$, hypochlorite $(5 \%)$ salicylic acid $(4 \%)$ and sorbitol $(3 \%)$, were detected during present study. The proportion of samples adulterated with various adulterants varied in different studies. When water is added in milk, its foamy appearance diminishes, so to give milk a foamy appearance artificially detergents are added in it. $20 \%$ of detergents adulteration in pure cow milk is used to enhance the cosmetic nature of milk [8 and 28]. 93.33, 86.66, 34 and $13 \%$ samples were found to be positive with cane sugar, urea, formalin and starch [29]. It is of interest to note that the middlemen attempt to counter the dilution by adding cane sugar to extend the solids content of the milk or as additives for the purpose of masking the effect of dilution of water [6 and 30]. Similarly, 12\% samples in summer, $10 \%$ in rainy and $2 \%$ in winter season found to be adulterated with formaldehyde, $5 \%$ with sodium chloride and $2 \%$ with starch. Starch, wheat flour, arrowroot and rice flour are added for increasing the solids not fat (SNF) content of milk [31]. Starch is used to increase the viscosity and total up to an accepted level of consumers [7 and 32]. $2.08 \%$ milk samples were found contaminated with formaldehyde [33]. In the present study 19\% samples were adulterated with sodium, similar adulterant was detected with the concentration of $8 \%$ samples in summer, $4 \%$ in rainy and $3 \%$ in winter season among a total 120 samples analyzed in 3 different seasons [31]. In Brazil, sodium chloride was added in milk to mask the high water content [34]. Further, the findings of present study regarding milk samples adulterated with skimmed milk powder and glucose are also supported by literature 44.69 and $70.42 \%$ milk samples positive to skimmed milk powder and glucose [35 and 36]. Ammonium sulfate ( 0.5 to $5 \%$ ) was used as an additive for the purpose of masking the effects of dilution of water in the milk. Hydrogen peroxide, formalin, boric acid, benzoic and salicylic acid are used as chemical preservatives for milk. These are usually used to increase the shelf life of milk during summer season when environmental temperature is very high. This unethical activity is usually adopted by the milk traders to prevent the financial losses due to the spoilage of milk during its transportation and sale [37 and 5]. In Kenya raw milk samples were analyzed for adulteration of hydrogen peroxide and $23.5 \%$ samples were found positive for hydrogen peroxide. Similarly, In Turkey the milk adulterated with benzoic acid at the low levels was widely used for the preparation of milk products [38]. In Pakistan, vegetable oil was added in milk by removing the true fat and cream from it to maintain the fat ratio by milk traders [25]. Similarly, caustic soda, sodium carbonate and bicarbonate are frequently used to neutralize the $\mathrm{pH}$ and acidity of milk by the milk traders in Pakistan [7]. In India, $27 \%$ milk samples in winter and $12 \%$ in summer and $10 \%$ in rainy season were found to be adulterated with carbonates/bicarbonates. In present study it was observed that the percentage of adulteration at dairy shop (DS), milk collectors and middlemen was significantly $(\mathrm{P}<0.05)$ higher than that of processors and milk producers, respectively [39]. These results are in line with the observations of other researchers. In Pakistan raw milk is distributed by a traditional system which involves middlemen called $\square$ Gawalas $\square$. These milk dealers; middlemen and dairy shop keepers adulterate milk to maximize their profit [29 and 5].

\section{Conclusions}

Accumulating evidence has shown that, on the basis of freezing point temperature of control milk, majority of milk samples from different intermediaries were found to be adulterated with extraneous water. The water was the most common adulterant found in majority of market milk samples followed by detergent, cane sugar, starch, rice flour, formalin, sodium chloride, skimmed milk powder, urea, hydrogen peroxide, ammonium sulfate, vegetable oil, boric acid, caustic soda, glucose, arrowroot, hypochlorite, salicylic acid and sorbitol sold at the vicinity of Hyderabad district of Sindh, Pakistan. The extent of extraneous water and risk of adulteration at dairy shops (DS), milk collectors (MC) and middlemen (MM) was remarkably higher as compared to processors (P) and milk producers (MP).

\section{Acknowledgement}

We are very thankful to Higher Education Commission (HEC), Islamabad, Pakistan for awarding Indigenous 5000 $\mathrm{PhD}$ fellowship. This portion of $\mathrm{PhD}$ research work on $\square$ Detection and extent of extraneous water and adulteration in milk consumed at Hyderabad, Pakistan $\square$ is fully supported by the Higher Education Commission (HEC) Islamabad, Pakistan. 


\section{References}

[1] Neumann, C.G., Harris, D.M. and Rogers, L.M. (2002). Contribution of animal source foods in improving diet quality and function in children in the developing world. Nutrition Research, 22, 193-220.

[2] Hoppe, C., Molgaard, C. and Michelson, K.F. (2006). Cow's milk and linear growth in industrialized and developing countries. Annual Review of Nutrition, 26, 131-173.

[3] Tipu, M.Y., Altaf, I., Ashfaq, M. and Siddiqui, S. (2007). Introduction. In: Proceedings of the workshop on monitoring of chemical adulterants and hygienic status of market milk. Lahore, Pakistan: WTO-Quality Control Laboratory, (pp. 7-39).

[4] Javaid, S.B., Gadahi, J.A., Khaskheli, M., Bhutto, M.B., Kumbher, S. and Panhwar, A.H. (2009). Physical and chemical quality of market milk sold at Tandojam. Pakistan Journal of Nutrition, 29 (1): 27-31.

[5] Naz, W. (2000). Subject: The dairy sector. http://www. Pakistaneconomist.com. Accessed Feb. 2011.

[6] Fakhar, H. and Law Walker, F.G. (2006). The white revolution-dhoodh darya. Pakistan Dairy Development Company, (pp. 72).

[7] Tariq, M.A. (2001). Subject: A close look at dietary patterns http://www.dawn.com/2001/11/05/ebr13. Htm. Accessed Feb, 2011.

[8] Walker, G.P., Dunshea, F.R. and Doyle, P.T. (2004). Effects of nutrition and management on the production and composition of milk fat and protein. Australian Journal of Agriculture Research, (55): 1009-1028.

[9] Haasnoot, W., Smits, N.G., Voncken, A.E.K. and Bremer, M.G. (2004). Fast biosensor immunoassays for the detection of cows' milk in the milk of ewes and goats. Journal of Dairy Research, 71, 322-329.

[10] Beall, D.P, and Scofield, R.H. (1995). Milk-alkali syndrome associated with Calcium carbonate consumption. Reports of seven patients with parathyroid hormone levels and an estimate of prevalence among patients hospitalized with hypocalcaemia. Medicine, 74 (2): 89-96.

[11] Rideout, T.C., Liu, Q., Wood, P. and Fan, M.Z. (2008). Nutrient utilization and intestinal fermentation are differentially affected by the consumption of resistant starch varieties and conventional fibers in pigs, British Journal of Nutrition, 99, 984-92.

[12] Ayub, M., Ahmed, Q., Abbas, M., Qazi, I.M., \& Hattak, I.A. (2007). Composition and adulteration analysis of milk samples, Sarhad Journal of Agriculture, 23 (4): 1127-1130.

[13] Gwin, M.C., Lienert, G. and Kennedy, J. (2009). Formaldehyde exposure and asthma in children. A systematic review. Environment Health Perspective, 118, 313-317.

[14] See, A.S., Salleh, A.B., Bakar, F.A., Yusof, N.A., Abdulamir, A.S. and Heng, L.Y. (2010). Risk and health effect of boric acid. American Journal of Applied Sciences, 7, 620-627.

[15] Mota, F.J.M, Implvo, F. Cunha, S.C. Beatriz, M. and
Oliveira, P.P. (2003). Optimization of extraction procedures for analysis of benzoic and sorbic acids in foodstuffs. Food Chemistry, 3 (82), 469-473.

[16] Saad, B., Bari, M.F. Saleh, M.I. Ahmad K. and Talib, M.K.M. (2005). Simultaneous determination of preservatives in food stuffs using HPLC. Journal of Chromatography Analysis, (1073), 393.

[17] Li, Z., Wu, L.L. Wang, Y.P. Liu, A.M Zou, C.C and Zhao, Z.Y. (2009). Melamine contaminated milk products induced urinary tract calculi in children. World Journal of Pediatrics, 5 (1), 31-35.

[18] Gale, F., \& Hu, D. (2007). Supply chain issues in China's milk adulteration incident. Economic Research Service U. S. Department of Agriculture Washington, DC.

[19] Khaskheli, M. (2010). Dairy Laboratory Manual. Department Animal Products Technology, Faculty Animal Husbandry and Veterinary Sciences, Sindh Agriculture University, Tandojam, (pp.38).

[20] AOAC, (2000). Official methods of analysis of the association of official analytical chemists. Inc. Gaithersburg, U.S.A.

[21] Butt, M.-Y.M. (2011). Seminar on Milk Anti-adulteration policy Policy Draft: International executive summary dairy report, (IFCN) Pak. Lahore.

[22] Nida, S., Soomro, A.H. Sheikh, S.A. and Khaskheli, M. (2013). Extent of water adulteration and its influence on physical characteristics of market milk. Pakistan Journal of Nutrition, 12 (2): 178-181.

[23] Meredith, P., Williams, P., Zampa, N., Garry, E., \& Ouattara, G. (2007). The effect of raw milk storage conditions on freezing point, $\mathrm{pH}$ and impedance. Advance Instruments, INC., (pp: 1-7).

[24] Bhatt, S.R., Singh, A., \& Bhatt, S.M. (2008). Assessment of synthetic milk exposure to children of selected population in Uttar Pradesh, India. Indian Journal of Research, 7, 22-34.

[25] Zia, U. (2007). Improved market access and smallholder dairy farmer participation for sustainable dairy development. Consultancy Report CFC/FIGMDP/ 16FT. Lessons Learned Study. Islamabad, Pakistan.

[26] Zia, U. (2006). Analysis of milk marketing chain, Pakistan. FAO. Food Laws Manual. 2006.

[27] Bhatti, M.Y. (2010). Formalin in milk consultancy report of Lahore High court. Free News alerts sums' PT to 9900.

[28] Manish, M.P., Singhal, R.S. and Kulkarni, P.R. (2000). An approach to the detection of synthetic milk in dairy milk, 1 . Detection of urea. International Journal of Dairy Technology, 53(3): 987-91.

[29] Lateef, M., Faraz, A. Mustafa, M.I., Akhtar, P. and Bashir, M.K. (2009). Detection of adulterants and chemical composition of milk supplied to canteens of various hospitals in Faisalabad city. Pakistan Journal of Nutrition, (9):139-142.

[30] Singhal, R.S., Kulkarni, P.R. and Rege, D.V. (1997). Handbook of Indices of food quality and authenticity Cambridge England Wood Head Publishing Limited, p.168174 
[31] Wadekar, S. B. and Menkudale, G.V. (2011). Physicochemical quality of market milk in Nanded town. Vision Research Review. I (I): p.27.

[32] Afzal, A., Mahmood, M.S., Hussain, I., \& Akhtar, M. (2011). Adulteration and microbiological quality of milk. Pakistan Journal of Nutrition, 10 (12): 1195-1202.

[33] Ibtisam, E., El- Zubeir, M. and El- Owni, O.A.O. (2009). Antimicrobial resistance of bacteria associated with raw milk contaminated by chemical preservatives. World Journal of Dairy and Food Science, 4 (1): 65-69.

[34] Fertig, C.C., Podczeck, F., Jee, R.D. and Smith, M.R. (2004). European Journal of Pharmacology Science, 2, 155.

[35] Pitty, (2011). 69 PC milk samples fail quality test some contain detergents. A national survey on milk adulteration. Conducted by Food Safety and Standards Authority of India. Reported by PTI.
[36] Sinha, K. (2012). $70 \%$ of milk in Delhi, country is adulterated consultancy Report http://timesofindia.indiatimes.com/topic/Food-SafetyStandards-Authority-of- India.

[37] Goswami, T.K., \& Gupta, S.K. (2008). Detection of dilution of milk with the help of glass transition temperature by differential scanning calorimetry (DSC). African Journal of Food Science, 2, 7-10.

[38] Yildiz, A., Erdogan, S., Saydut, A., \& Hamamci, C. (2012). High-Performance Liquid Chromatography analysis and assessment of benzoic acid in yogurt, ayran, and cheese in Turkey. Food Analytical Methods. (5): 591-595.

[39] Sanjeevani, B.W., Chavan, B.R. and Menkudale, G.V. (2011). Survey on adulteration of the milk received from Government milk scheme in banded town. Journal of International link Research Analysis, 1 (4): 32-35. 